\title{
EFFECT OF LACTIC ACID PRODUCING BACTERIA ON SOME POTENTIAL PATHOGENS IN SAUSAGE
}

\author{
AZHAR MOHAMED HASAN AHMED* and LUBNA MOHAMED IBRAHIM ELWY* \\ *Animal Health Research Institute Assiut laboratory \\ Email: $\underline{\text { aaa_mmm_1993@yahoo.com }}$
}

\begin{tabular}{|c|c|}
\hline & ABSTRACT \\
\hline Received at: $31 / 12 / 2014$ & $\begin{array}{l}\text { A total of } 128 \text { isolates of lactic acid bacteria (LAB) were isolated from hundred } \\
\text { sausages samples collected from different supermarkets in Assiut City. The obtained } \\
\text { isolates were identified bacteriologically as Pediococcus cervisiae (35), } \\
\text { Enterococcus faecium (25), Lactobacillus brevis (12), Lactobacillus acidophilus } \\
\text { (12), Lactobacillus bulgaricus (12), Lactobacillus fermetni (12), Streptococcus } \\
\text { thermophilus (10) Lactococcus garvieae (10). Then they were screened for } \\
\text { antagonistic activity against listeria monocytogenes, Staphylococcus aureus, } \\
\text { Escherichia coli and Salmonella Typhimurium using agar well diffusions method. } \\
\text { All these isolates exhibited antibacterial activity against L.monocytogenes and } \\
\text { E.coli, the most active strain against both pathogens was Pediococcus cervisiae, } \\
\text { whereas Enterococcus faecium, Streptococcus thermophilus and Lactococcus } \\
\text { garvieae. were not active against, Staphylococcus. aureus, also Lactobacillus brevis, } \\
\text { Lactobacillus acidophilus, Lactobacillus fermenti and Lactococcus garvieae were } \\
\text { not active against Salmonella Typhimurium. }\end{array}$ \\
\hline
\end{tabular}

Key words: lactic acid bacteria, Lactobacillus acidophilus Staphylococcus aureus, Escherichia coli.

\section{INTRODUCTION}

Lactic acid bacteria refers to a large group of beneficial bacteria that have similar properties and all produce lactic acid as an end product of the fermentation process. They are widespread in nature and are also found in our digestive systems. Although they are best known for their role in the preparation of fermented dairy products, they are also used for pickling of vegetables, curing fish, meats and sausages, in addition to flavoring foods and inhibiting pathogenic as well as spoilage bacteria in these products (Morsi et al., 2003).

The general description of the bacteria included in this group is gram-positive, non-spore forming, cocci or rods, it is nutritionally fastidious, requiring carbohydrates, amino acids, peptides, nucleic acids and vitamins. Recent taxonomic revisions of these genera suggest that the lactic acid bacteria comprise the following: (Aerococcus, Carnobacterium, Enterococcus, Lactobacillus, Lactococcus, Lecunostoc, Pediococcus, Streptococcus, Tetragenococcus, Vagococcus, and Weissella) (Rattanachaikunsopon and Phumkhachorn, 2010).

The classification of $\mathrm{LAB}$ into different genera is largely based on morphology, mode of glucose fermentation, growth at different temperatures, configuration of the lactic acid produced, ability to grow at high salt concentration and acid or alkaline tolerance. $\mathrm{LAB}$ can be mainly divided into two groups based on the end-products formed during the fermentation of glucose. Homofermentative LAB such as Pedicoccus. Streptococcus, Lactococcus and some Lactobacilli produce lactic acid as the major or sole end-product of glucose fermentation. Heterofermetnive LAB such as weissella, leuconostoc and some lactobacilli produce equimolar amounts of lactate, $\mathrm{CO}_{2}$ and ethanol from glucose. (De Vuyst and vandamme, 1993) and (Axelsson et al., 1998).

The preservative action of starter culture in food system is attributed to the combined action of a range of antimicrobial metabolites produced during the fermentation process (Caplice and fizgerald, 1999). These include many organic acids such as lactic, acetic and propionic acids produced as end products which provide an acidic environment unfavourable for the growth of many pathogenic and spoilage microorganisms.

In addition to acids, starter strains can produce a range of other antimicrobial metabolites such as ethanol, $\mathrm{H}_{2} \mathrm{O} 2$ and diacetyl (Daeschel, 1989). Other examples of secondary metabolites produced by LAB 
which have antagonistic activity include the compound reuterin (Axelsson et al., 1989) and the recently discovered antibiotic reuterocyclin (Ganzle, 2000), both of which are produced by strains of Lactobacillus reuteri. Also L.A.B are known to produce compounds named "bacteriocins" (Geis et al., 1983; Klaenhammer, 1988). Which are relatively small peptides, senstive to specific proteolytic enzymes, can be heat stable and have either bacteriocidal or baceriostatic activity against closely related, or in some casses a wide spectrum of microorganisms including food borne pathogens such as Listeria monocytogenes and some lostridia. This makes bacteriocin producers particulary for potential use in food preservation.

Nisin is the only bacterioicin with GRAS (Generally regarded as safe) status for use in specific foods and was further supported by the accumulated data indicating its nontoxic and nonallergenic nature, it is produced by strains of Lactococcuslactis and can prevent out growth of Bacillus and Clostridium spores (Daeshel, 1989).

Thus it is possible to use LAB for the treatment of different gastrointestinal disease (Ljungh and Wadstrom, 2009) and for foods preservation (Labioui et al., 2005; Cocolim et al., 2007; Dorlu and Thonart, 2009; Kouakou and Thonart, 2011) due to their antibacterial properties.

LAB have a very important role in the formation of the specific organoleptic characteristics of dry sausages, as well as the prevention of growth of pathogenic microorganism in this product (Zeljka et al., 2012).

The objectives of this study were to isolate $\mathrm{LAB}$ as ferments present in sausages, evaluate the antibacterial activity of the isolates against L.monocytogenes, S.aureus, E.coli, and S.typhimurium and to select strains that could be used in sausages production.

\section{MATERIALS and METHODS}

\section{Collection of samples:}

Hundred sausage samples of various brands were collected from different supemarkets in Assiut City. The samples were freed aseptically from its casings and placed in clean bags and transferred to laboratory for microbiological study.

Isolation of LAB: (De Man et al., 1960)

One gram of each sample was aseptically transferred to sterile MRS broth. Inculcated tubes were abaerobically incubated at $37^{\circ} \mathrm{C}$ for $48-72$ hours in $\mathrm{Co}_{2}$ incubator, and next the broth was cultured on
MRS-agar plates, then incubated under anaerobic conditions at $37^{\circ} \mathrm{C}$ for $48-72$ hours. Colonies of acidproducing bacteria identified by a clear zone around each colony, were randomly selected and purified by replating on MRS agar plates. After obtaining pure culture, Gram-stain, motility and biochemical tests were performed for identification purposes.

\section{I-Identification of isolates:}

Gram's stain (APHA, 1992):

LAB are Gram-positive, non-spore forming, cocci or rods.

Motility test (Baron et al., 1994):

Tubes of semisolid medium were inoculated with a pure culture of suspected isolates by stabbing to a depth of approximately $2 \mathrm{~cm}$ with a bacteriological needle. After overnight incubation at suitable temperature, motility was evident as a haze of growth extending into the agar from the stabbing line. Growth of non-motile organism is restricted only to the stabbing line.

\section{П-Biochemical identification:}

1- Catalase test (Land et al., 1991):

A drop of $3 \%$ hydrogen peroxide was placed on a clean microscopic slide. A visible amount of bacterial growth was added with the inoculating loop. Both were mixed and observed for gas bubble production.

\section{2-Oxidase test (Baron et al., 1994):}

By a sterile platinum loop, one colony was taken and rubbed in circles on a strip of filter paper impregnated with oxidase reagent (1\% solution of tetramethy1-Pphenylene Diamine-Dihydrochloride). Appear-ance of dark purple color within 5-10 seconds indicated positive results while, no change in color means negative.

\section{3-Indole production test (Koneman et al., 1992):}

Tryptone water tubes were inoculated with a pure culture of the tested organism. Inoculated tubes were incubated at $35^{\circ} \mathrm{C}$ for $18-24$ hours, and then drops of Kovac's reagent were added down the inner wall of the tubes. Development of a bright fuchsin red color at the interfere of the reagent and the broth within seconds indicated positive test, while no change in the broth indicated negative test.

\section{4-Growth at $15^{\circ} \mathrm{C}, 37^{\circ} \mathrm{C}$ and $45^{\circ} \mathrm{C}$ (Collins and Lynes, 1989): \\ Inoculate the isolated organism in MRS broth tubes and incubate at $15^{\circ} \mathrm{C}, 37^{\circ} \mathrm{C}$ and $45^{\circ} \mathrm{C}$ and look for growth.}

\section{5-Carbohydrate fermentation (Collins and Lynes, 1989):}

Inoculate the isolated organisms in MRS broth tubes containing the following sugars: lactose, sucrose, 
mannitol, xylose, maltose and trehalose in concentration of $1 \%$ and with $0.05 \%$ phenol red as indicator. Tubes were incubated at $37^{\circ} \mathrm{C}$ and results recorded daily up to 7 days. Appearance of yellow color indicated sugar assimilation.

\section{6- Nitrate reduction test (Mackie and McCartney, 1989):}

The isolated strains were inculcated into nitrate broth and incubated at $37^{\circ} \mathrm{C}$ for 96 hours. After that $0.1 \mathrm{ml}$ of the nitrate test reagent was added to the test culture. A red color developing within a few minutes indicated the presence of nitrite and hence the ability of the organism to reduce nitrate, while no change in color means negative results.

\section{7- Arginine hydrolysis (Collins and lynes, 1989):}

In MRS broth replaces the ammonium citrate by $0.3 \%$ arginine, the isolated strain was inoculated and incubated at $28-30^{\circ} \mathrm{C}$ for 3-4 days. A positive reaction indicating hydrolysis of arginine with the formation of ammonia which causes alkalinity in the medium and denoted by changing the yellow medium into a distinct red or pink color.

\section{8-Growth at 4\% NaCI (Peter et al., 1986):}

MRS broth containing $4 \mathrm{~g}$ of $\mathrm{NaC} 1$ was inoculated with the isolated strains and incubated at $37^{\circ} \mathrm{C}$ for 24 hours and examined for growth.

\section{III-Detection of antibacterial activity:}

The agar-well diffusion method was used to detect and determine the antibacterial activities of the isolated strains in which Listeriamonocytogenes (NCIB No 8588), Escherichia coli (NCPC No 12023), Staphylococcus aureus (NCPC No 7447), Salmonella Typhimurium (NCPC No 12241) were used as indicator bacteria for detection of the antibacterial activity, all strins mentioned were obtained from High Quality Meida Unit (HQM) in Animal Health Research Institute in Dokki, Egypt, the pathogens were maintained in Brain Heart infusion Agar (BHIA) butt- slants in screwcapped tubes kept at $4^{\circ} \mathrm{C}$.

Strains were propagated in a tryptone soya broth of $24 \mathrm{hrs}$ culture at $37^{\circ} \mathrm{C}$.

IV- Bacteriocin activity assay (Geis et al., 1983):

The isolated strains that were selected as potential bacteriocin producers were grown in MRS broth at $37^{\circ} \mathrm{C}$ for 48 hours. Cells were separated by centrifugation at $5000 \mathrm{rpm}$ for 10 minutes. The $\mathrm{pH}$ of the cell free supernatant was adjusted to 5.5 with sterile $0.2 \mathrm{~N} \mathrm{NaOH}$. Bacteriocin activity in the supernatant was tested by agar well diffusion assay.

\section{Agar well diffusions method:}

$20 \mathrm{ml}$ of molten nutrient agar medium were cooled at $47^{\circ} \mathrm{C}$ and seeded with $1 \%$ overnight culture of each indicator organism separatly. Seeded agar was poured into sterile petridish and allowed to solidify at room temperature. Wells of $7 \mathrm{~mm}$ diameter were cut in the solidified agar using a sterile metal cork borer and filled with $100 \mu \mathrm{L}$ of supernatant bacteriocin. The plates were left at $4-5^{\circ} \mathrm{C}$ for 2 hours to allow diffusion of the substances and then incubated in $\mathrm{Co}_{2}$ incubator for 24 hours at temperature optimum for the indicator organism $37^{\circ} \mathrm{C}$. Absence or presence of inhibition zones as well their diameters were recorded.

Another nutrient agar plates were seeded with $1 \%$ overnight culture of each indicator organism and used as control in which the wells were filled with sterile distil water and incubated at $37^{\circ} \mathrm{C}$ for 24 hours. Absence or presences of inhibition zones were recorded.

\section{RESULTS}

Table 1: Incidence of isolated strains of LAB from sausages samples.

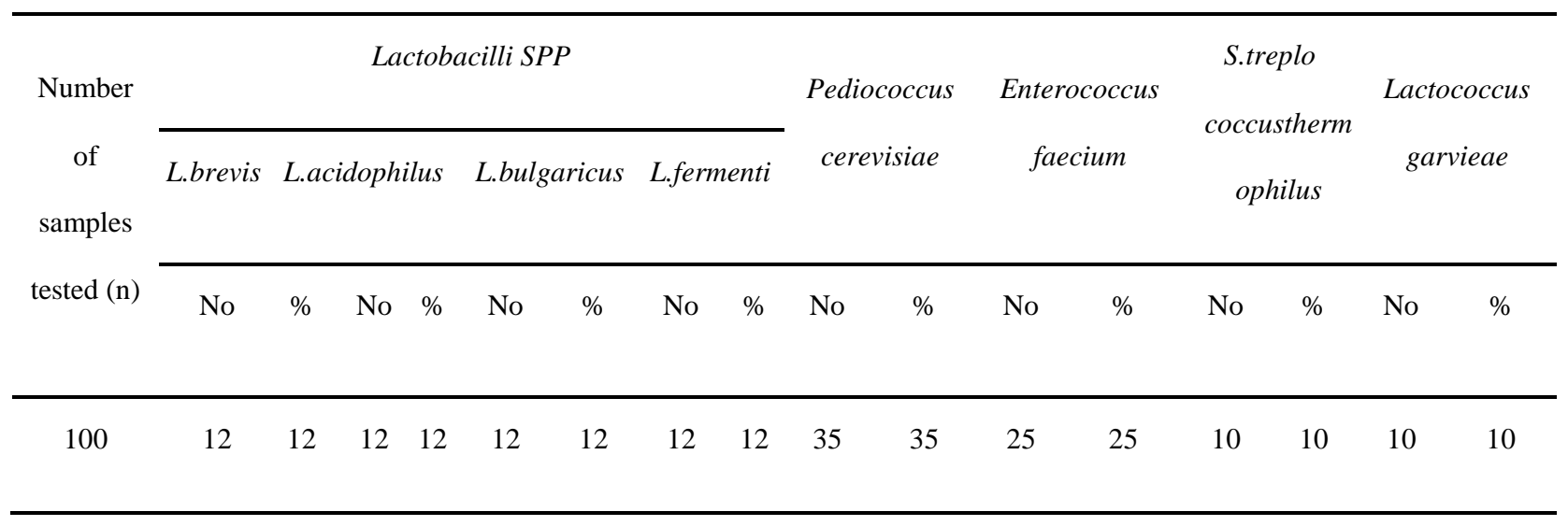


Table 2: Antibacterial activity of the isolated strains against some pathogenic microorganisms.

\begin{tabular}{|c|c|c|c|c|c|c|c|c|}
\hline \multirow{2}{*}{$\begin{array}{l}\text { Isolated } \\
\text { strains }\end{array}$} & \multicolumn{8}{|c|}{ Zone of inhibition(mm) } \\
\hline & control & $\begin{array}{c}\text { Listeria } \\
\text { monocytogenes }\end{array}$ & control & Staph.aureus & control & E.coli & control & $\begin{array}{l}\text { S.typhim- } \\
\text { urium }\end{array}$ \\
\hline L.brevis & $\mathbf{0}$ & 1.3 & $\mathbf{0}$ & 0.92 & $\mathbf{0}$ & 2.4 & $\mathbf{0}$ & 0.25 \\
\hline L.acid & $\mathbf{0}$ & 0.79 & $\mathbf{0}$ & 0.53 & $\mathbf{0}$ & 1.84 & $\mathbf{0}$ & 0.1 \\
\hline L.bulgaricus & $\mathbf{0}$ & 2.5 & $\mathbf{0}$ & 1.5 & $\mathbf{0}$ & 1.6 & $\mathbf{0}$ & 0.6 \\
\hline L.fermenti & $\mathbf{0}$ & 1.5 & $\mathbf{0}$ & 1.86 & $\mathbf{0}$ & 1.9 & $\mathbf{0}$ & 0.36 \\
\hline Ped.cerevisiae & $\mathbf{0}$ & 2.8 & $\mathbf{0}$ & 0.82 & $\mathbf{0}$ & 2.5 & $\mathbf{0}$ & 1.9 \\
\hline Ecfaecium & $\mathbf{0}$ & 0.9 & $\mathbf{0}$ & 0.28 & $\mathbf{0}$ & 0.96 & $\mathbf{0}$ & $\mathbf{0 . 8 3}$ \\
\hline S.thermophilus & $\mathbf{0}$ & 1.9 & $\mathbf{0}$ & 0.25 & $\mathbf{0}$ & 1.8 & $\mathbf{0}$ & 0.78 \\
\hline Lc.garvieae & $\mathbf{0}$ & 0.7 & $\mathbf{0}$ & 0.34 & $\mathbf{0}$ & 0.81 & $\mathbf{0}$ & 0.2 \\
\hline
\end{tabular}

\section{DISCUSSION}

Lactic acid bacteria originally isolated from traditional sausages are probably the best candidates for improving the microbiological safety of these foods, because they are well adapted to the conditions in sausages and should there fore be more competitive than LAB from other sources (Salim et al., 2006).

Naturally, different microorganisms derived from raw materials and the environment contaminate dry sausage mixtures. Among them, LAB are found to be the most active microorganisms in sausages (Sawitzki et al., 2007).

In this study 8 strains were isolated from 100 collected samples of sausages. The strains were identified as showen in table (1) as Pediococcus cerevisiae (35), Enterococcus faecium (25), Lactobacillusbrevis (12) Lactobacillus acidophils (12), Lactobacillus bulgaricus (12), Lactobacillus fermenti (12), Streptococcus thermophilus (10) and Lactococcus garvieae (10). This indicated that the most isolated LAB was assigned to Lactobacillas species $(48 \%)$, this observation is very close to the data of the (Erkkila et al., 2001) who also pointed out that Lactobacillus species are the dominate microflora in fermented sausages. (Zeljka et al., 2012) reported that the majority of the strains isolated from the Croatian dry fermented sausages were assigned to the species L.plantarum and L.brevis. Also other Lactobacilli such as L.plantarumL. casei, L.brevis and L.alimentarius could be isolated as well by (Rantsiou and cocolin, 2008).

Some authors indicated that the most frequent isolates of LAB in the fermentation process of dry sausages from European countries are L.sakei, L.curvatus and L.plantarum (Gurakan et al., 1995; Santos et al.,
1998; Samelis et al., 1998; Erkkila et al., 2001; Aymerich et al., 2003; Papamanoli et al., 2003; Drosinos et al., 2005; Gasparik- Reichardt et al., 2005; Rantsiou et al., 2006; Drosinos et al., 2007; Kozacinski et al., 2008; Mozzi et al., 2010).

This variation in the recovered stains of Lactobacilli isolated by the previous authors may be due to the difference in the composition of dry sausages from region to region and there are also difference in the technological production process.

On the other hand both of Streptococcus thermophilus and Lactococcus garvieae were isolated from much fewer samples $(10 \%)$ for each as showed in (table 1), also this table reported the percentages of Pediococcs cerevisiae and Enterococcus faecium they were 35\% and $25 \%$ respectively.

In industries which process animal based products, overall Listeria SPP, are a major problem for this industry and although chemicals such as $\mathrm{Na} \mathrm{No}_{2}$ can inhibit Listeria and other pathogens in sausages, such substances may represent health risks for consumers and there is a constant demand for new preservative agents (Montville and Winkowski, 1997; Cleveland et al., 2001).

Some authors (De martinis and Freilas, 2003; Tyopponen et al., 2003 and Dicks et al., 2004) have suggested the use of bacteriocinogenic LAB as starter cultures in food preservation.

For this reason the isolated strains of LAB in our study were screened for antagonistic activity against some pathogenic microorganisms (Listeria monocytogenes, Staphylococcus aureus, Escherichia coli and Salmonella typhimurium) to evaluate the 
antibacterial activity of these isolates against the indicator organisms.

According to the results recorded in table (2) the most active strain against L.monocytogens was Pediococcus cerevisioae with an inhibition zone (2.8) $\mathrm{mm}$ followed by Lactobacillus bulgaricus with an inhibition zone (2.5) $\mathrm{mm}$, while Stryptoccus thermophilus, Lactobaccillus and Lactobacillusbrevis showed an inhibition zones (1.9, 1.5 and 1.3) mm respectively.

Other strains, Enterococcus faecium, Lactobacillus acidophilus and Lactococcus garvieae showed a weak inhibition zones $(0.9,0.79$ and 0.7$) \mathrm{mm}$ respectively.

As the results indicate, the zones of inhibition were varied, ranging between $(0.7$ to 2.8$) \mathrm{mm}$. this revealed that all isolated strains inhibited L.monocytogenes according to (Schillinger and Lucke, 1989) who mentioned that inhibition was scored positive if the width of the Pediococcus cervisiae (35), Enterococcus faecium (25), Lactobacillus brevis (12), Also table (2) showed that most active strains against Staphylococcus aureus were Lactobacillus fermetniand Lactobacillus bulgaricus with an inhibition zones (1.86 and 1.5) $\mathrm{mm}$ respectively and the least active strains against this organism were Lactobacillus brevis (12), Pediococcus cervisiae and Lactobacillus acidophilus with an inhibition zones (0.92, 0.82 and 0.53) respectively, while the strains Pediococcus cervisiae, Enterococcus faecium and Streptococcus thermophilus showed no inhibitory effect against Staphylococcus aureus, according to (Schillinger and Lucke, 1989), that their inhibition zones less than $0.5 \mathrm{~mm}$. The fact that no inhibition was noticed by these strains against Staphylococcus aureus, may be an indication that their initial activities were due to the organic acid secretion such as lactic acid, while the activity of the other strains is an indication of the presence of other antibacterial substances such as peroxides, diacetyls and baceriocins.

These observations are in agreement with those reported by (Ogunbanwa et al., 2003) who showed that L.brevis excreted other compounds such as bacteriocins that inhitited the growth of pathogens.

The ability of Enterococcus faecium species isolated from fermented sausages to display antibacterial activity against Listeria and Staphylococcus aureus, species was reported by several authors (Cintas et al., 1997; Callewaert et al., 2000 and Herranz et al., 2001), this agreement with our study in which Enterococcus faecium showed antibacterial activity against Listeria. monocytogenes, and disagreement with our study in which the same strain showed no inhibitory effect against Staphylococcus aureus. Regarding the data presented in the same table it was found that all isolated strains were active against Gram-negative E.coli., the most active strain against this organism was Pediococcus cervisiae with an inhibition zone (2.5) $\mathrm{mm}$. and the least active one was Lactococcus garvieae with an inhibition zone (0.81) $\mathrm{mm}$. On the other hand 4 of the isolated strains were not active against Gram-negative Salmonella typhimurium they were Lactobacillus. brevis Lactobacillus acidophilus, Lactobacillus. fermenti and Lactococcus garvieae, in which their inhibition zones less than $(0.5) \mathrm{mm}$. according to (Schillinger and Lucke, 1989).

The antimicrobial activity of LAB against Gramnegative organismses could not be detected by many authers (Steven et al., 1991; Hechard et al., 1992 and Mathieu et al., 1993), also (Gao et al., 1999) reported that the outer membrane of Gram-negative bacteria may protect the cytoplasmic membrane from the action of the antimicrobial compound, whereas (Jay 1982) reported that Diacetyl is an aroma component produced by strains within all genera of LAB and inhibits the growth of Gram-negative organisms by reacting with arginine utilization.

\section{CONCLUSION}

In this study the most active strain against listeria monocytogene, E coli and Salmonella typhimurium was Pediococcuscerevisioae while the most active strain against Staphyloccocus asureus was Lactobaccillus. Fermenti. This inhibition is possibly due to the fact that LAB produce various compounds such as organic acids, diacetyl, hydrogen peroxide and bacteriocin in the course of their metabolism.

\section{REFERENCES}

A.P.H.A. (American public Health Association) (1992): Standard Methods for the examination of dairy products. $16^{\text {th }}$ Ed. American pubic Health Association, New York.

Axelsson, L.T.; Chung, T.C.; Dobrogosz, W.J. and Lindgren, S.E. (1989): Production of a broad spectrum antimicrobial substance by lactobacillus reuteri. Microbial Ecology in health and disease (2): 131-136.

Axelsson, L.; Salminen, S. and Von wright, A. (1998): Lactic acid Bacteria. Microbiology and functional Aspects, 2 ${ }^{\text {nd }}$ Edition, (Marcel Dekker Inc, New York). 1-72.

Aymerich, T.; Martin, B.; Garriga, M. and Hugas, M. (2003): Microbial quality and direct PCR identification of lactic acid bacteria and nonpathogenic staphylococci from artisan lowacid sausages Appl. Environ. Microbiol. 69: 4538-4594.

Baron, E.J.; Peterson, L.R., and Finegold, S.M. (1994): Bailey and Scott's Diagnostic 
Microbiology, $9^{\text {th }}$ ed., st. Louis, Baltimore, USA, Chapter 34: PP. 457-473.

Callewaert, R.; Hugas, M. and De Vuyst, L. (2000): Competitiveness and baceteriocin production of enterococci in the production of Spanishstyle dry fermented sausages. International $\mathbf{J}$. of Food Microbiology. 57: 33-42.

Caplice, E. and fitzgerald, G.F. (1999): Food fermentation: role of microorganisms in food production and preservation. Int. J. Food microbiol. 50 (1-2): 131-149.

Cintas, L.M.; Casaus, P.; Hoavarstein, L.S., Hernadez, P.E. and Nes, I.F. (1997): Biochemical and genetic characterization of enterocin P, a novel sec. dependent baceriocin from entercoccusfaecium P13 with a broad antimicrobial spectrum. Applied and Environmental Microbiology 63: 4321-4330.

Cleveland, J.; Montville, T.J.; Nes, I.F. and Chikindas, M.L. (2001): Bacteriocins safe natural antimicrobials for food preservation. International. J. of food Mic. 71: 1-20.

Collins, A. and Lynes, P. (1989): Microbiological Methods $6^{\text {th }}$ ed. Butler and Tunner, from somerset Great Britain. PP: 233-241.

Cocololin, L.; Foschino, R.; Comi, G. and Fortian, M.G. (2007): Descriplion of the baceriocins produced by two strains of enterococcus faecium isolated from Italian goat milk. Food microbiology. 31: 753-758.

Daeschel, M.A. (1989): Antimicrobial substances from lactic acid bacteria fro use as food preservation food technology 43: 164-167.

De Man, J.D.; Rogosa, M.A and Sharpe, M.E. (1960): A medium for the cultivation of lactobacilli. J. Appl. Bact. 23; 130-135.

De Martinis, E.C. and Freitas, F.Z. (2003): Screening of lactic acid bacteria from Brazilian meats for baceriocin formation food control. 14: 197-200.

De vuyst, L. and Vandamme, E.J. (1993): Bacteriocin of lactic acid bacteia. Blackie Academic \& Professional, California.1-12.

Dicks, L.M.; Mellett, F.D. and Hoffman, L.C. (2004): Use of baceriocim producing starter cultures of lactobacillus plantarum and Lactobacillus curvatus in production of ostrich meat salami. Meat science. 66: 703-709.

Dorlu, C. and Thonart, P. (2009): Les baceriocines des bakeries lactiques: caracteristiqueset interest pour la boconservation des produitsalimentaires. Biotechnol. Argon. Soc. Environ. 13 (1): 143-154.

Drosinos, E.H.; Mataragas, M.; Xiraphi, N.; Moschonas, G.; Gaitis, F. and Metaxopoulos, J. (2005): Characterisation of the microbial floar from a traditional Greek fermented sausage. Meat Sci. 69: 307-317.

Drosinos, E.H.; Paramithiotio, S.; Kolovos, G.; Tsikouras, I. and Metaxopoulos, I. (2007):
Phenotypic and technological diversity of lactic acid bacteria and staphylococci isolated from traditional fermented sausages in southern Greece. Food microbiol. 24: 260-270.

Erkkila, A.S.; Petaja, E.; Eerola, S.; Lilleberg, L.; Mattila-Sandholm, T. and Suihko. M.L. (2001): Flavour profiles of dry sausages fermented by selected movel meat starter cutures. Meat Sci. 58: 111-116.

Ganzle, M.G.; HoHzel, A.; Walter, J.; Jung, G. and Hammes, W.P. (2000): Characteization of reutericylin produced by lactobacillus reuteri LTH 2584. Appl. Environ. Microbiol. 66: 4325-4333.

Gao, Y.; Yan Belkum, M.J. and Stiles, M.E. (1999): The outer membrane of Gram-negative baceria inhibits antibacterial activity of bacerionic C. Applied and Environmental Microbiology 65: 4329-4333.

Gasparik-Reichard, T.J.; Toth, S.; Cocolin, L.; Comi, G.; Drosinos, E.H.: Crtila, Z.; Kozacinski, L.; SmaJlovic, A.; Saicic, S. and Borovic, B. (2005): Technological physicochemical and microbiological characeeristics of traditionally fermented sausages in mediterran and central European countries. Meat Technol. 46: 143-135

Geis, A.; Singh, J. and Teuber, M. (1983): Potential of lactic streptococci to produce baceriocin. Applid and Environmental Microbiology. 45: 205-211.

Gurakan, G.C.; Bozoglui, T.F. and Weis, N. (1995): Identification of lactobacillus strains from Turkish-style dry fermented sausages. Food sci. technol. 28: 139-144.

Hechard, Y.; Derijard, B.; Letellier, F. and cenatiempo, $Y$. (1992): Characterizaiton and purification of mesentericin y 105, an antilisteria baceriocin from leuconostoc messenteroides. Journal of General Microbiology 138: 2725-2731.

Herranz, C.; Casaus, P.; Mukhopadhyay, S.; Martnez, J.M.; Rodrguez, J.M. and Nes, I.F. (2001):Enterococus faecium P21: Astrain occurring naturally in dry fermented sausages producing the class II bacterioins enterocin A and enercin B. Food Microbiology 18: 115-131.

Jay, J.M. (1982): Antimicrobial properties of diacety. Applied and environmental microbiology, 44: 525-532.

Klaenhammer, T.R. (1988): Baceriocins of lactic acid bacteria. Biochimie 70: 337-349.

Koneman, E.W.; Allen, S.D.; Janda, W.M.; Schreckenberger, P.C. and Winn, W.C. (1992): Diagnostic microbiology $4^{\text {th }}$ ed. Philadelphia: JB Lippincott.

Kouakou, P. and thonart, P. (2011): Action des cultures protectrices: acs des germes lactiquessur la flore alimentaire indesirbable 
Biotechno. Agron. Soc. Environ. 15 (2): 339-348

Kozacinski, L.; Drosinos, E.; Caklovica, F.l.; Cocolin, L.l.; Gasparic.Reichard, J. and Veckovic, S. (2008): Investigation of microbiological association of traditional fermented sausages. Food technol. Biotechno 46: 93-106.

Labioui, H.L.; Elmoualdi, L.; El yachioui, M. and Ouhssine, M. (2005): Selection de souches de bacterieslactiquesantibaceriennes. Bull. Soc. Pharm Bordeaux. 144: 237-250.

Land, G.; Mcginnis, M.R.; Staneck, J. and Gaston, A. (1991): Aerobic pathogenic Actinomycetales. In Balows, A; Hauster, W. J. (ed.), Manual of clinical microbiology, $5^{\text {th }}$ ed. Amercian society for microbiology, Washington, D. C. PP. 340-360.

Ljungh, A. and Wadstrom, T. (2009): Lactobacillus Molecular Biology: from genomics to probiotics caister Academic Press. ISBN 9781-904455 - 41-7.

Mackie and McCartney (1989): Practical Medical Microbiology, $13^{\text {th }}$ ed., Volume 2 of medical microbiology.

Mathieu, F.; Suwandhi, S.; Rekhif, N.; Milliere, J.B. and lefebure, G. (1993): Mesentercin 52, a bacteriocin produced by leuconoe stoc mesenteroides ssp. Mesenteroides FR 52. Journal of Applied Baceriology 74: 372-379.

Montville, T.J. and Winkowski, K. (1997): Biologically based preservation systems and probiotic baceria. In M. P. Doyle, L. R. Beuchat and T. J. Montville (Eds.). Food Microbiology: Fundamentals and frontiers (PP. 557-576). USA: ASM press.

Morsi, E.; Ahmed, N.; Omran, N.; Osman, G. and Morsi, A. (2003): Isolation, identification and selection of lactic acid bacteria cultures for cheesemaking. Emir. J. Agric. Sci. 15 (2): 51-71.

Mozzi, F.; Raya, R.R. and Vignolo, G.M. (2010): New approaches for the study of lactic acid baceria biodiversity: A focus on meat ecosystem in: biotechnology of LAB. No. vel. Applications (Mozzi, F.; Raya, R. R>, Vignolo, G. M. Eds).Blackwell publishing pp. 251-272.

Ogunbanwa, S.; Sanni, A. and Onilude (2003): Characterization of baceriocin produced by lactobacillus plantarum F1 and lactobacillus brevis. Afri. J. Biotochnol.2; 219-227.

Papamanol, E.; Tzatanetakis, N.; LitopoulouTzanetaki, E. and Kotzekidou, P. (2003): Characterisation of LAB isolated from Greek dry fermented sausages in respect of their technological and probiotic properties. Meat Sci. 652 859-867.

Peter, H.A.; Nicholas, S.M.; Elisabeth, M.S. and John, G.H. (1986): Bergey's Manual of systematic Baceriology (Volume lactobacilli and Bifidobaceria.

Rantisiou, K. and Cocolin, L. (2008): Fermented meat products In: Moleualr techniques in the microbial ecology of fermented foods. (Cocolin, L. and Ercolini D. Eds). Springer.

Rantsiou, K.; Drosinos, E.H.; Gialitaki, M.; Metaxopoulos, I.; Comi, G. and Cocolin, L. (2006): Use of molecular tools to characterize lactobacillus spp. Isolated from Greek traditional fermented sausages. Int. J. food Micro biol. 112: 215-222.

Rattanachaikunsopon, $P$. and phumkhachorn, $P$. (2010): Lactic acid bacteria: their antimicrobial compounds and their uses in food production. Annals of Biological Research. 1(4): 218-228.

Salim, A.; Gregoire, T.; Eric., D. and Isabelle, $C$. (2006): Antibacterial activity of lactic acid bacteria against spoilage and pathogenic bacteria isolated from the same meat smallscale facility. Food control (17): 454-461.

Samelis, J.; Metaxopoulos, J.; Valssi, M. and Pappa, A. (1998): Stability and safety of traditional Greek salami-a microbiological ecology study. Int. J. food Microbiol. 44: 69-82.

Santos, E.M.; Gonzales-fernandez, C.; Jaime, I. and Rovira, J. (1998): Comparative study of LAB house flora isolated different varieties of "chorizio" Int. J. food Microbiol. 39: 123-128.

Sawitizki, M.C.; Fiorentini, A.M.; Angonesibrod, F.C.; Tagliari, C.; Bertol, T.M.; Maisonnave Arisi, A.C. and santanna, E.S. (2007): Phenotypic characterization and speciesspecific PCR of promising starter culture strains of lactobacillus plantarum isolated from naturally fermented sausages. Brazilian J. Microbiol. (38): 547-552.

Schillinger, U. and Lucke, F. (1989): Antimicrobial activity of lactobacillus sake isolated from meat. J. Appl., Environ Microbiol. 55: 1901-1906.

Stevens, K.A.; Sheldon, B.W; Klapes, N.A. and Klaenhammer, T.R. (1991): Nisin treatment for inactivation of slamonella species and other Gram-negative bacteria-Applied Environmental Microbiology 57: 3613-3615.

Tyopponen, S.; Markkula, A.; Petaja, E.; Suihko, M.L. and Mattilasand holm, T. (2003): Survival of listeria monocytogenes in North European type dry sausages fermented by bioprotective meat starter cultures. Food control. 14: 181-185.

Zeljka, C.F.; Vladimir, S.; Lidija, K.; Bela, N.; Nevijo, Z. and Ivana, F. (2012): Identification of lactic acid bacteria isolated from dry fermented susages. Veterinarskiarhiv 82 (3), 265-272. 


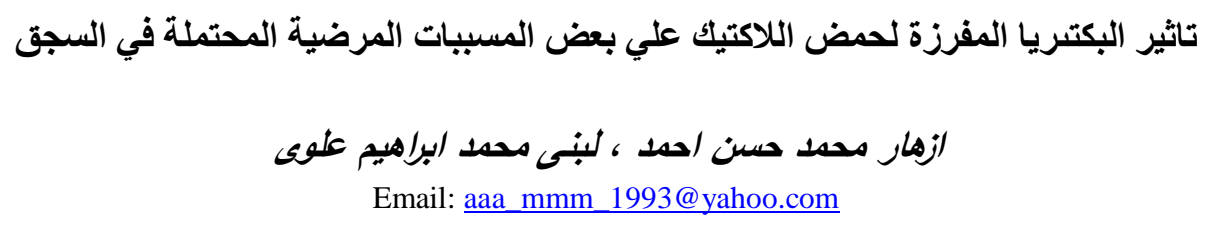

Email: aaa_mmm_1993@yahoo.com

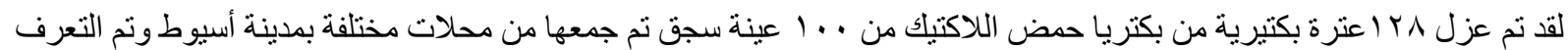

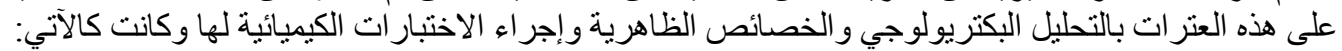
Lactobacillus bulgaricus (12), Enterococcus faecium (25).Pediococcuscervisiae(35), Lactobacillus acidophilus (12), Lactobacillus fermetni (12), Streptococcus thermophilus (10), Lactococcusgarvieae (10 Lactobacillus brevis (12))

وبدر اسة التأثير المثبط لهذه العتر ات ضد ميكروب الليستيريا مونوسيتوجين و المكور العنقودي الذهبي و الميكروب القولوني وسالمونيلا

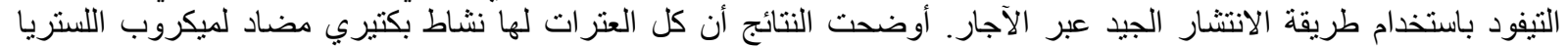

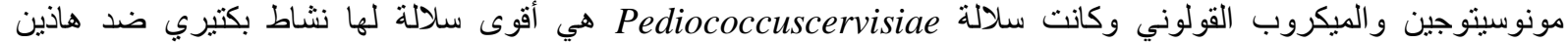

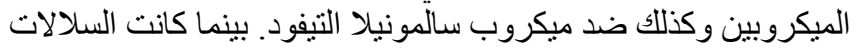

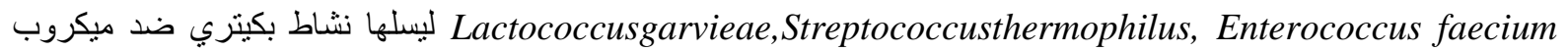
Lactobacillus fermetni, Lactobacillus acidophilus Lactobacillus المكور العنقودي الذهبي وكذللك السلالات

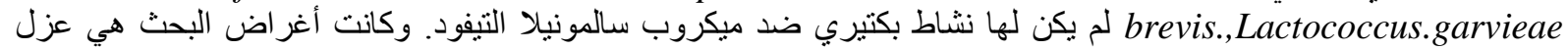

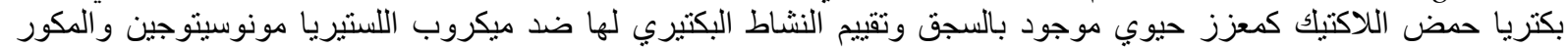
العنقودي الذهبي و الميكروب القولوني وسئ وسالمونيلا التيفود و اختيار أفضل السلالات التي يمكن أن تستخدم في إنتاج السجن. 